\title{
PEMANFAATAN TEKNOLOGI INFORMASI DAN KOMUNIKASI DALAM PEMBELAJARAN BAGI PARA GURU SMPN 2 KAWALI DESA CITEUREUP KABUPATEN CIAMIS
}

Budiana, H.R., Sjafirah, N.A. dan Bakti, I.

Fakultas Ilmu Komunikasi, Universitas Padjadjaran E-mail:

\begin{abstract}
ABSTRAK
Pengembangan dan penggunaan Teknologi Informasi dan komunikasi (TIK) dalam pendidikan dapat membuat reformasi untuk sistem pendidikan yang lebih baik. Ketika survei pertama di SMP (SMP) Negeri 2 Kawali, guru menghadapi beberapa kesulitan dalam menerapkan (ICT) dalam proses belajar mengajar di sekolah, karena tidak adanya infrastruktur seperti laboratorium komputer, jaringan internet, serta penguasaan TIK dari guru. Program pelayanan masyarakat seperti pelatihan ICT untuk guru di SMPN 2 Kawali, Desa Citereup dengan memberikan pengetahuan dan penggunaan ICT dalam proses pembelajaran. Metode yang digunakan adalah: ceramah, diskusi, dan praktek / pelatihan. Aplikasi mereka ditawarkan adalah flash, e-learning, pembelajaran sistem manajemen hanya merupakan pengantar saja dan lebih dalam di Microsoft Word. Setelah menghadiri acara pelatihan ini, guru memiliki pengetahuan dan pemahaman tentang keragaman aplikasi ICT. Selain itu, motivasi besar bangkit dari guru untuk dapat mengontrol dan mengoptimalkan penggunaan ICT untuk mengajar dan belajar di kelas.
\end{abstract}

\begin{abstract}
ABSTRACK
The development and the use of Information and communication Technology (ICT) in education can make the reformation for a better education system. When the first survey in Junior High School (SMP) Negeri 2 Kawali, teachers faced some difficulties in implementing (ICT) in teaching and learning at schools, due to the absence of infrastructure such as computer labs, Internet network, as well as the mastery of ICT from the teachers. Community service programs such as ICT training for teachers in SMPN 2 Kawali, Citereup village by providing the knowledge and use of ICT in the learning process. The methods used are: lectures, discussion, and practice/training. The application they are offered are flash, e-learning, learning management system is only an introduction only and more deeper in Microsoft Word. After attending this training event, teachers have the knowledge and understanding of the diversity of ICT applications. In addition, big motivations rise from teachers to be able to control and optimize the use of ICT for teaching and learning in the classroom.
\end{abstract}

\section{PENDAHULUAN}

Berkembangnya kemajuan Teknologi Informasi dan komunikasi (TIK) dewasa ini telah memberi pengaruh besar dalam seluruh aspek kehidupan, termasuk dunia pendidikan. Pengembangan dan pemanfaatan TIK dalam dunia pendidikan dapat menjadikan reformasi sistem pendidikan menjadi lebih baik.

Beragam kemampuan TIK yang luar biasa sudah seharusnya dimanfaatkan dalam dunia pendidikan dalam kerangka melahirkan sistem pendidikan yang lebih baik, baik dalam aspek sarana prasarana, peningkatan profesionalisme kualitas sumber daya manusia pendidik (guru) maupun menghasilkan anak didik yang berkualitas.

Permasalahan yang muncul seiring dengan pemanfaatan TIK dalam dunia pendidikan adalah faktor penguasaan TIK oleh para guru. Sebagaimana kita ketahui, dalam pendidikan di sekolah guru adalah motor utama penggerak dalam pelaksanaan pembelajaran. Dalam proses pembelajaran tersebut TIK sebagai sarana yang dapat membantu tugas para guru agar proses belajar mengajar baik di dalam mupun diluar kelas menjadi lebih baik. Oleh karenanya penguasaan TIK oleh para guru menjadi keharusan dalam rangka meningkatkan profesionalisme guru.

Penguasaan TIK dikalangan para guru, khususnya para guru di pedesaan menjadi masalah besar yang harus dicarikan solusi. Potret buram dunia pendidikan di Indonesia salah satu nya adalah tidak merata nya kondisi pendidikan di perkotaan dan di pedesaan, baik aspek sarana prasarana pendidikan sampai pada kualitas gurunya.

Gambaran nyata kondisi pendidikan di pedesaan terlihat di Sekolah Menengah Pertama (SMP) Negeri 2 Kawali, dimana pada saat survey awal terlihat bahwa para guru mengalam kesulitan dalam menerapkan Teknologi Informasi dan komunikasi (TIK) dalam proses belajar mengajar di sekolahnya, hal ini di karenakan ketiadaan sarana prasarana baik laboratorium komputer, jaringan internet sampai pada penguasaan para guru terhadap TIK nya itu sendiri. Hal ini lah yang menjadi dasar program pengabdian pada masyarakat dosen yang diintegrasikan dengan program kuliah kerja nya unpad untuk memberikan pelatihan TIK bagi para guru di SMPN 2 Kawali Desa Citereup dengan memberikan pelatihan pemanfaatan TIK dalam pembejalaran bagi para guru dalam upaya memberikan pengetahuan dan pemahaham pemanfaatan TIK.

\section{TINJAUAN PUSTAKA}

\section{Hakikat Teknologi Informasi dan Komunikasi (TIK)}

Teknologi Informasi dan Komunikasi (TIK) meliputi dua aspek, yaitu aspek Teknologi Informasi dan aspek Teknologi Komunikasi. Perbedaan Teknologi Informasi (TI) dan Teknologi Informasi dan Komunikasi (ICT) secara sederhana dikatakan Elston (2007), yaitu "IT as the technology used to managed information and ICT as the technology used to manage information and aid communication".

Teknologi Informasi dan Komunikasi (TIK) sebagai bagian dari Ilmu Pengetahuan dan Teknologi (IPTEK) secara umum adalah semua teknologi yang berhubungan dengan pengambilan, pengumpulan (akuisisi), pengolahan, penyimpanan, penyebaran 
dan penyajian informasi (Kementerian Negara Riset dan Teknologi RI, 2006: 6).

Pengertian TIK yang merupakan gabungan dari dua konsep yaitu Information Technology dan Communication Technology, di rumuskan oleh (UNESCO, 2003: 7), yaitu: Information technology is the term used to describe the items of equipment (hardware) and computer program (software) that allow us to access, store, organize, manipulate, and present information by electronic means. Communication technology is term used to describe telecommunication equipment, through which information can be sought and accessed.

Secara akademis, pengertian teknologi informasi dan teknologi komunikasi dapat dibedakan, akan tetapi pada prakteknya teknologi informasi dan komunikasi ibarat dua sisi mata uang, dimana keduanya sangat sulit dipisahkan.

Dalam konteks pembelajaran, menurut (Siahaan, 2010) penggunaan komputer ditekankan memang ditekankan, akan tetapi TIK bukan berarti terbatas pada penggunaan alat-alat elektronik yang canggih (sophisticated), seperti pemanfaatan komputer dan internet, melainkan juga mencakup alat-alat yang konvensional, seperti: bahan tercetak, kaset audio, Overhead Transparancy (OHT)/Overhead Projector (OHP), bingkai suara (sound slides), radio, dan Televisi.

TIK adalah semua teknologi yang berhubungan dengan pengambilan, pengumpulan (akuisisi), pengolahan, penyimpanan, penyebaran, dan penyajian informasi. Pemahaman ini sesuai dengan pengertian TIK yang dikemukakan oleh UNESCO di atas.

\section{Teknologi Informasi dan Komunikasi dalam Pembelajaran}

Pengertian kualitas pembelajaran Menurut Ismiati dalam makalahnya, adalah suatu kondisi yang menggambarkan tingkat efektivitas suatu pembelajaran. Pembelajaran yang efektif adalah pembelajaran yang menfasilitasi peserta didik aktif berinteraksi dengan berbagai sumber belajar sehingga peserta didik mencapai tujuan-tujuan pembelajaran secara efektif, efisien, dan menyenangkan (berdaya tarik). Peningkatan kualitas pembelajaran berarti upaya-upaya yang dilakukan dalam mewujudkan dan meraih tingkat kualitas pembelajaran yang diharapkan.

TIK dalam pembelajaran dapat di bagi atas dua peran, yaitu: (1) sebagai media presentasi pembelajaran, misal berbentuk slide power point dan animasi dengan program flash; (2) sebagai media pembelajaran mandiri atau E-Learning, misal peserta didik diberikan tugas untuk membaca atau mencari sumber dari internet, mengirimkan jawaban tugas, bahkan mencoba dan melakukan materi pembelajaran. Melalui E-Learning, belajar tidak lagi dibatasi oleh ruang dan waktu. Belajar dapat dilakukan kapan saja dan dimana saja. Hal ini mendorong peserta didik untuk melakukan analisis dan sintesis pengetahuan, menggali, mengolah dan memanfaatkan informasi, menghasilkan tulisan, informasi dan pengetahuan sendiri. Peserta didik dirangsang untuk melakukan eksplorasi ilmu pengetahuan. Fasilitas yang dapat dimanfaatkan oleh peserta didik untuk belajar melalui E-Learning diantaranya: E-Book, E-Library, interaksi dengan pakar, email, mailling List, News Group, dan lain-lain.

Sedangkan manfaat penggunaan TIK dalam rangka mendukung pelaksanaan pembelajaran adalah:

(1) meningkatkan kualitas pembelajaran;

(2) memperluas akses terhadap pendidikan dan pembelajaran;

(3) membantu memvisualisasikan ide-ide abstrak;

(4) mempermudah pemahaman materi yang sedang dipelajari;

(5) menampilkan materi pembelajaran menjadi lebih menarik; dan

(6) memungkinkan terjadinya interaksi antara pembelajaran dengan materi yang sedang dipelajari.

Jika memperhatikan manfaat dari penggunaan TIK ini, tentunya penggunaan TIK dalam pembelajaran maupun lingkungan sekolah tidak dapat dihindari. Sekolah harus senantiasa berupaya untuk memenuhi kebutuhan terhadap fasilitas TIK ini.

Pemanfaatan TIK dalam pembelajaran menjadi tuntutan yang mendesak dewasa ini. Maraknya arus informasi dan ragamnya sumber informasi menjadikan guru tidak menjadi satu-satunya sumber belajar. Akan tetapi dalam satuan pendidikan sekolah guru memiliki peranan yang strategis. Oleh karena itu penggunaan TIK di sekolah hendaknya dimulai dari titik pangkal yang strategis pula yaitu guru (Miarso, 2004: 494).

Para guru harus diyakinkan bahwa TIK memiliki kegunaan dalam memfasilitasi proses belajar siswa dan bahwa TIK tidak akan menggantikan kedudukannya sebagai guru, melainkan membantunya untuk, paling tidak, menyimpan dan menyajikan konsep, prinsip, prosedur yang ingin diajarkannya. Upaya strategis yang perlu dilakukan adalah para guru perlu ditingkatkan kepercayaan dirinya serta dilibatkan dan ikut berpartisipasi dalam pengembangannya, yaitu pengembangan TIK untuk pembelajarannya demi peningkatan kualitas proses dan hasil belajar siswa.

\section{METODE YANG DIGUNAKAN}

Dalam kegiatan penyuluhan dan pelatihan ini pendekatan yang digunakan bersifat 'persuasif-edukatif', dengan ini dimaksudkan untuk memberikan pengetahuan, pemahaman, dan keterampilan dalam menggunakan TIK bagi pembelajaran. Adapun metode yang digunakan adalah: ceramah, diskusi, dan praktek/latihan.

\section{HASIL DAN PEMBAHASAN}

Pengabdian berupa pelatihan pemanfaatan Teknologi Informasi dan Komunikasi dalam Pembelajaran bagi Para Guru SMPN 2 Kawali dilaksanakan dengan meminjam ruangan pertemuan SMPN 2 Kawali. Melalui kegiatan pelatihan ini diharapkan para guru dapat memperoleh pengetahuan, pemahaman dan keterampilan menggunakan teknologi informasi dan komunikasi bagi optimalisasi proses belajar mengajar di kelas.

Kegiatan pelatihan ini direncanakan diikuti sekitar 25 orang guru, tetapi 3 orang guru berhalangan hadir, maka pelatihan diikuti oleh 23 orang guru, terdiri atas 9 orang guru wanita dan 14 orang guru pria. Selain itu hadir pula Kepala Sekolah SMPN 2 Kawali merangkap peserta, Wakasek merangkap komite dan peserta, serta Kepala Desa Citereup 
merangkap komite sekolah.

Kegiatan pelatihan ini diawali dengan penyampaian materi melalui metode ceramah mengenai pengenalan TIK serta bagaimana TIK dapat dimanfaatkan bagi proses pembelajaran serta ragam aplikasi yang dapat digunakan untuk membantu para guru dalam pembelajarannya . Pada pemaparan materi ini, sudah terlihat bagaimana peserta merespon dengan positif, dimana terkadang disela-sela pemaparan ada pertanyaaan yang muncul dari peserta pelatihan. Hal ini dikarenakan sebagian peserta belum mengenal aplikasiaplikasi tersebut, tetapi mereka menunjukan keinginan belajarnya dengan sesekali bertanya. Pada sesi ini juga ditawarkan aplikasi yang akan di fokuskan untuk diperdalam, karena tidak mungkin seluruh aplikasi dapat diberikan dan dikuasai oleh kegiatan yang singkat seperti ini. Aplikasi yang ditawarkan adalah flash, e-learning, learning management system dan microsoft word. Di sepakati oleh seluruh peserta bahwa untuk flash, e-learning dan learning management system hanya pengenalan saja, sedangkan microsoft word karena berkaitan dengan keseharian mereka sedikit lebih mendalam.

Kegiatan dilanjutkan dengan pemaparan pengenalan aplikasi flash bagi pembelajaran, pada materi ini peserta diberikan pengantar dan beberapa contoh flash yang dapat meningkatkan minat siswa pada belajar dikarenakan tampilan yang menarik sehingga tidak menimbulkan kebosanan dalam belajar yang dilanjutkan dengan membuka sesi tanya jawab. Ketika sesi ini tanya jawab terlihat antusiasme peserta dengan banyak nya pertanyaan khususnya berkenaan dengan mata pelajaran yang mereka pegang untuk dimungkinkan atau tidak menggunakan aplikasi flash.

Materidilanjutkanmengenaipengenalane-learning sebagai aplikasi pembelajaran jarak jauh, dalam kondisi sekolah seperti SMNP 2 Kawali yang memiliki banyak kekurangan khususnya sarana dan prasarana masih sangat sulit menerapkan aplikasi e-learning seperti ini, sehingga para guru pun kurang begitu antusias ketika menyadari untuk menggunakannya dibutuhkan selain keterampilan juga sarana pendukungnya, akan tetapi untuk bekal pengetahuan para guru menjadi lebih mengetahui bahwa e-learning sangat bermanfaat bagi proses pembelajarannya.

Kegiatan dilanjutkan dengan materi pengenalan learning management system, dimana aplikasi ini memungkinkan para guru untuk mengelola kegiatan pembelajarannya, mulai dari mengelola kelas, mengelola materi, membuat bank soal sampai pada evaluasi pembelajarannya. Ini menjadi sesuatu yang menarik bagi para guru dan menjadi pengetahuan berharga, akan tetapi mereka menyadari kembali pada kemampuan SDM dan sarana bahwa hal ini butuh waktu untuk mereka dapat menguasai dan melaksanakannya.

Sedangkan materi praktek atau latihan dititik beratkan pada optimalisasi microsoft word dalam penulisan karya ilmiah. Hal ini dapat dilakukan karena word biasa mereka gunakan untuk pengetikan seharihari, tetapi bagaimana mengoptimlkannya mereka tidak mengetahui dan menguasainya. Sehingga ketika materi ini dilakukan langsung fokus tidak pada dasar-dasar word akan tetapi sudah pada bagaimana tools pada word digunakan, serta diberikan latihan untuk prakteknya. Terlihat para guru begitu senang ketika mengetahui banyak sekali tools yang selama ini mereka tidak mengetahui cara menggunakannya tetapi sangat membantu dalam pembuatan karyakarya tulis, seperti membuat style, daftar isi, daftar pustaka dan lain sebagainya.

Secara umum para guru peserta pelatihan terlihat antusias mengikuti kegiatan pelatihan ini, terlebih bagi guru-guru yang menyadari betul bahwa TIK sangat berguna dalam membantu pembelajaran. Mereka merasa terbantu dengan adanya kegiatan pelatihan ini sebagai sarana untuk menambah motivasi, pengetahuan, pemahaman dan keterampilan dalam memanfaatkan TIK bagi pembelajaran. Semua pihak, khususnya Para Guru peserta pelatihan menyadari bahwa dengan pelatihan singkat semacam ini tidak mungkin para guru dapat menguasai TIK dalam pembelajaran dengan baik, terutama bagi mereka yang sama sekali tidak pernah menggunakan TIK, akan tetapi setidak nya pelatihan ini menumbuhkan motivasi dan pengetahuan akan manfaat TIK bagi pembelajaran, yang dapat di tularkan sebagai motivasi kepada para siswa untuk melek teknologi.

\section{SIMPULAN}

Setelah dilakukan kegiatan pelatihan kepada Guru-guru SMPN 2 berupa pemanfaatan TIK bagi pembelajaran diperoleh beberapa kesimpulan sebagai berikut:

1. Tumbuh motivasi besar dari para guru ditengah beragam kesulitan yang mereka hadapi untuk dapat menguasai TIK bagi proses belajar mengajar di kelas.

2. Secara umum para guru di pedesaan khususnya SMPN 2 Kawali kurang memadai SDM nya untuk dapat mengoptimalkan penggunaan TIK bagi pembelajaran.

3. Pengetahuan dan pemahaman para guru mengenai ragam aplikasi TIK yang dapat digunakan bagi pembelajaran mengalami peningkatan.

\section{DAFTAR PUSTAKA}

Elston, Carol, 2007, Using ICT in the Primary School, Sage Publications,

London.

Jumali, M, dkk. 2004. Landasan Pendidikan. Surakarta: UMS Press

Sudjana, N., Achmada Rivai, 2001, Teknologi Pengajaran, Bandung,

Penerbit Sinar Baru Algensindo

Seels, Barbara B, dan Richey, (1994), Instructional Technology: the

Definitions and Domains of the Field, Whashington DC: AECT

Sudirnan Siahaan (2010), Pemanfaatan Teknologi Informasi dan

Komunikasi dalam Pembelajaran. Jakarta: Pustekkomdiknas 
Moore, Peter, Environment of e-learning, UNESCO, 2003

Elhafidz, Muhammad, 2011, Pendekatan Penerapan ICT, dalam http://mutamad-elhafidz.blogspot. com/2011/12/makalah-pendekatan-penerapanict.html

Muhammad Anas, 2008, makalah yang disajikan dalam simposium pendidikan, Pemanfaatan Teknologi Informasi dan Komunikasi (TIK) dalam Pembelajaran di Provinsi Sulawesi Tenggara.

Christina Ismaniati, makalah, Penggunaan Teknologi Informasi Dan

KomunikasiDalamPeningkatan Kualitas Pembelajaran, FIP-Universitas Negeri Yogyakarta 